\title{
Emended description of Campylobacter sputorum and revision of its infrasubspecific (biovar) divisions, including $C$. sputorum biovar paraureolyticus, a urease-producing variant from cattle and humans
}

1 Danish Veterinary Laboratory, Bülowsvej 27, DK-1790 Copenhagen V, Denmark

2 Department of Veterinary Science, University of Bristol, Bristol, UK

${ }^{3}$ Department of Medical Microbiology, University of Aberdeen, Aberdeen, UK

4 Laboratorium voor Microbiologie, University of Ghent, B-9000, Ghent, Belgium

5 Department of Medical Microbiology, University of Antwerp, B-2610 Antwerp, Belgium

\author{
S. L. W. On, ${ }^{1}$ H. I. Atabay, ${ }^{2}$ J. E. L. Corry, ${ }^{2}$ C. S. Harrington ${ }^{1,3}$ \\ and P. Vandamme ${ }^{4,5}$
}

Author for correspondence: S. L. W. On. Tel: +45353001 00. Fax: +4535300120. e-mail: sto@svs.dk

Keywords: Campylobacter sputorum biovar paraureolyticus

\section{INTRODUCTION}

The genus Campylobacter was first proposed in 1963 and included two species, Campylobacter fetus and Campylobacter bubulus (36). This classification has since been extensively revised due to research demonstrating the ecological diversity and clinical importance of Campylobacter spp. [reviewed by (37)]; and also as a result of the use of improved taxonomic methods to elucidate interstrain relationships $(11,21$, 41-46). Consequently, [Vibrio] sputorum (32) and [Vibrio fecalis] (9) were assigned to the genus Campylobacter on the basis of DNA base composition and

\footnotetext{
Abbreviations: CNUPC, catalase-negative, urease-positive campylobacter; $\mathrm{H}_{2} \mathrm{~S} / \mathrm{TSI}$, hydrogen sulfide production in triple sugar iron; S-level, similarity level; UPGMA, unweighted pair group method with arithmetic averages.

The GenBank accession number for the BU 112B 16S rDNA sequence reported in this paper is AFO22768.
}

phenotypic characters $(5,46)$. Although Campylobacter sputorum and $C$. bubulus were initially considered related at the subspecific level (46), subsequent DNA homology studies clearly showed these taxa, and 'Campylobacter fecalis' also, to belong to the same species, C. sputorum $(13,33,39)$. Observations correlating biochemical differences between strains isolated from humans, the bovine and ovine genital tract and ovine faeces led to the infrasubspecific division of C. sputorum into three biovars, bv. sputorum, bv. bubulus and bv. fecalis (33). Conversely, an organism first isolated from pigs affected by proliferative enteritis and named C. sputorum subsp. mucosalis (17) demonstrated negligible levels of DNA-DNA homology to $C$. sputorum, and was thus considered a separate species, Campylobacter mucosalis (34). The status of $C$. sputorum and $C$. mucosalis as distinct species has since been extensively validated by various phenotypic and genotypic analyses $(7,22,26,40-41$, 43). 
Table 1. Strains used

Square brackets indicate that the species is generically misnamed and is regarded as a species incertae sedis (41). Previous designations are given in parentheses in the third column. Abbreviations: BU, Bristol University, Bristol, UK; CCUG, Culture Collection of the University of Göteborg, Sweden; CHY, C. hyointestinalis-like strain; CNUPC, catalase-negative, urease-positive campylobacter; LMG, Culture Collection, Laboratorium voor Microbiologie, Ghent, Belgium; NCTC, National Collection of Type Cultures, London, UK; ${ }^{\mathrm{T}}$, type strain.

\begin{tabular}{|c|c|c|c|}
\hline Organism & Strain number & Additional information & $\begin{array}{l}\text { Clinical and geographical } \\
\text { origin (if known) }\end{array}$ \\
\hline \multirow{27}{*}{$\begin{array}{l}\text { Campylobacter species } \\
\text { C. sputorum }\end{array}$} & & & \\
\hline & LMG 11764 & bv. paraureolyticus & Human diarrhoea, Canada \\
\hline & $\begin{array}{l}\text { LMG } 17590(=\text { BU 112B, } \\
\text { CCUG } 37579)\end{array}$ & $\begin{array}{l}\text { bv. paraureolyticus } \\
\text { (CNUPC group) }\end{array}$ & Bovine faeces, Bristol, UK \\
\hline & LMG 17593 (= BU 308B) & $\begin{array}{l}\text { bv. paraureolyticus } \\
\text { (CNUPC group) }\end{array}$ & Bovine faeces, Bristol, UK \\
\hline & LMG 17589 (= BU 464B) & $\begin{array}{l}\text { bv. paraureolyticus } \\
\text { (CNUPC group) }\end{array}$ & Bovine faeces, Bristol, UK \\
\hline & LMG 17592 (= BU 31C) & $\begin{array}{l}\text { bv. paraureolyticus } \\
\text { (CNUPC group) }\end{array}$ & Bovine faeces, Bristol, UK \\
\hline & LMG 17591 (= BU 73C) & $\begin{array}{l}\text { bv. paraureolyticus } \\
\text { (CNUPC group) }\end{array}$ & Bovine faeces, Bristol, UK \\
\hline & BU 150B & $\begin{array}{l}\text { bv. paraureolyticus } \\
\text { (CNUPC group) }\end{array}$ & Bovine faeces, Bristol, UK \\
\hline & BU 168B & $\begin{array}{l}\text { bv. paraureolyticus } \\
\text { (CNUPC group) }\end{array}$ & Bovine faeces, Bristol, UK \\
\hline & BU 751B & $\begin{array}{l}\text { bv. paraureolyticus } \\
\text { (CNUPC group) }\end{array}$ & Bovine faeces, Bristol, UK \\
\hline & BU 90B & $\begin{array}{l}\text { bv. paraureolyticus } \\
\text { (CNUPC group) }\end{array}$ & Bovine faeces, Bristol, UK \\
\hline & BU 132B & $\begin{array}{l}\text { bv. paraureolyticus } \\
\text { (CNUPC group) }\end{array}$ & Bovine faeces, Bristol, UK \\
\hline & BU 179B & $\begin{array}{l}\text { bv. paraureolyticus } \\
\text { (CNUPC group) }\end{array}$ & Bovine faeces, Bristol, UK \\
\hline & BU 333C & $\begin{array}{l}\text { bv. paraureolyticus } \\
\text { (CNUPC group) }\end{array}$ & Bovine faeces, Bristol, UK \\
\hline & BU $651 \mathrm{C}$ & $\begin{array}{l}\text { bv. paraureolyticus } \\
\text { (CNUPC group) }\end{array}$ & Bovine faeces, Bristol, UK \\
\hline & BU 86C ( = CCUG 37580) & $\begin{array}{l}\text { bv. paraureolyticus } \\
\text { (CNUPC group) }\end{array}$ & Bovine faeces, Bristol, UK \\
\hline & $\begin{array}{l}\text { LMG 7795 }(=\text { NCTC } \\
\left.11528^{\mathrm{T}}\right)\end{array}$ & bv. sputorum & Human oral cavity, USA \\
\hline & LMG 11761 & bv. sputorum & Human, Canada \\
\hline & LMG 11765 & $\begin{array}{l}\text { bv. sputorum (bv. } \\
\text { bubulus) }\end{array}$ & Human, Canada \\
\hline & LMG 14261 & bv. sputorum & $\begin{array}{l}\text { Human, pus from pressure } \\
\text { sore, Belgium }\end{array}$ \\
\hline & LMG 7975 (= CCUG 20706) & bv. sputorum & $\begin{array}{l}\text { Porcine intestine, Preston, } \\
\text { UK }\end{array}$ \\
\hline & $\begin{array}{l}\text { LMG } 10388(=\text { CCUG } \\
24261)\end{array}$ & bv. sputorum & $\begin{array}{l}\text { Ovine foetus, stillborn, } \\
\text { Huddinge, Sweden }\end{array}$ \\
\hline & LMG 8535 (= CCUG 22572) & bv. sputorum & Ovine faeces, Montana, USA \\
\hline & LMG 6447 (= NCTC 11367) & $\begin{array}{l}\text { bv. sputorum (bv. } \\
\text { bubulus) }\end{array}$ & $\begin{array}{l}\text { Bovine semen, Brussels, } \\
\text { Belgium }\end{array}$ \\
\hline & LMG 8531 (= NCTC 11415) & bv. fecalis & $\begin{array}{l}\text { Ovine faeces, Toronto, } \\
\text { Canada }\end{array}$ \\
\hline & LMG 8532 (= CCUG 20703) & bv. fecalis & Bovine faeces, Preston, UK \\
\hline & LMG 8534 (=CCUG 22571) & bv. fecalis & Ovine faeces, Montana, USA \\
\hline
\end{tabular}


Table 1 (cont.)

\begin{tabular}{|c|c|c|c|}
\hline Organism & Strain number & Additional information & $\begin{array}{l}\text { Clinical and geographical } \\
\text { origin (if known) }\end{array}$ \\
\hline & $\begin{array}{l}\text { LMG } 6728(=\text { CCUG } \\
17695 \mathrm{~B})\end{array}$ & bv. fecalis & $\begin{array}{l}\text { Ovine faeces, geographic } \\
\text { source unknown }\end{array}$ \\
\hline & LMG 6618 (= CCUG 12017) & bv. fecalis & $\begin{array}{l}\text { Ovine faeces, Toronto, } \\
\text { Canada }\end{array}$ \\
\hline & LMG 6617 (= CCUG 12015) & bv. fecalis & $\begin{array}{l}\text { Ovine faeces, Toronto, } \\
\text { Canada }\end{array}$ \\
\hline & LMG $8536(=$ CCUG 22580) & bv. fecalis & Ovine faeces, Montana, USA \\
\hline C. coli & $\begin{array}{l}\text { LMG } 8847^{\mathrm{T}}(=\text { NCTC } \\
\left.11366^{\mathrm{T}}\right)\end{array}$ & Penner serotype 4 & $\begin{array}{l}\text { Porcine faeces, Brussels, } \\
\text { Belgium }\end{array}$ \\
\hline C. concisus & $\begin{array}{l}\text { LMG } 7788^{\mathrm{T}}(=\text { NCTC } \\
\left.11485^{\mathrm{T}}\right)\end{array}$ & & $\begin{array}{l}\text { Human gingival sulcus, } \\
\text { Boston, USA }\end{array}$ \\
\hline C. curvus & $\begin{array}{l}\text { LMG 7609 } \\
\left.11649^{\mathrm{T}}\right)\end{array}$ & & $\begin{array}{l}\text { Human, alveolar abscess, } \\
\text { Virginia, USA }\end{array}$ \\
\hline C. fetus subsp. fetus & $\begin{array}{l}\text { LMG } 8849^{\mathrm{T}}(=\text { NCTC } \\
\left.10842^{\mathrm{T}}\right)\end{array}$ & & $\begin{array}{l}\text { Ovine, foetus brain, Paris, } \\
\text { France }\end{array}$ \\
\hline C. fetus subsp. venerealis & $\begin{array}{l}\text { LMG 6443" } \\
\left.10354^{\mathrm{T}}\right)\end{array}$ & & $\begin{array}{l}\text { Bovine, heifer vaginal mucus, } \\
\text { Reading, UK }\end{array}$ \\
\hline \multirow[t]{2}{*}{ C. gracilis } & NCTC $12738^{\mathrm{T}}$ & & $\begin{array}{l}\text { Human, periodontitis, } \\
\text { Boston, USA }\end{array}$ \\
\hline & $\begin{array}{l}\text { LMG } 14731(=\text { CCUG } \\
13143)\end{array}$ & & \\
\hline C. helveticus & $\begin{array}{l}\text { LMG } 12638^{\mathrm{T}}(=\text { NCTC } \\
\left.12470^{\mathrm{T}}\right)\end{array}$ & & $\begin{array}{l}\text { Feline, faeces, Berne, } \\
\text { Switzerland }\end{array}$ \\
\hline $\begin{array}{l}\text { C. hyointestinalis subsp. } \\
\text { hyointestinalis }\end{array}$ & $\begin{array}{l}\text { LMG } 7817^{\mathrm{T}}(=\text { NCTC } \\
\left.11608^{\mathrm{T}}\right)\end{array}$ & & $\begin{array}{l}\text { Porcine intestine, } \\
\text { proliferative enteritis, } \\
\text { Minnesota, USA }\end{array}$ \\
\hline C. hyointestinalis subsp. lawsonii & LMG $14432^{\mathrm{T}}\left(=\right.$ CHY $\left.5^{\mathrm{T}}\right)$ & & Porcine stomach, UK \\
\hline C. jejuni subsp. doylei & $\begin{array}{l}\text { LMG } 8843^{\mathrm{T}}(=\text { NCTC } \\
\left.11951^{\mathrm{T}}\right)\end{array}$ & & $\begin{array}{l}\text { Human, infantile diarrhoea, } \\
\text { Adelaide, Australia }\end{array}$ \\
\hline C. jejuni subsp. jejuni & $\begin{array}{l}\text { LMG } 8841^{\mathrm{T}}(=\text { NCTC } \\
\left.11351^{\mathrm{T}}\right)\end{array}$ & Penner serotype 23 & $\begin{array}{l}\text { Bovine faeces, Brussels, } \\
\text { Belgium }\end{array}$ \\
\hline C. lari & $\begin{array}{l}\text { LMG } 8846^{\mathrm{T}}(=\text { NCTC } \\
\left.11352^{\mathrm{T}}\right)\end{array}$ & & $\begin{array}{l}\text { Herring gull, cloacal swab, } \\
\text { UK }\end{array}$ \\
\hline C. mucosalis & $\begin{array}{l}\text { LMG 6448 } \\
\left.11000^{\mathrm{T}}\right)\end{array}$ & Serotype A & $\begin{array}{l}\text { Porcine, small intestine, } \\
\text { porcine intestinal } \\
\text { adenomatosis, Edinburgh, } \\
\text { UK }\end{array}$ \\
\hline C. rectus & $\begin{array}{l}\text { LMG 7613 } \\
\left.11489^{\mathrm{T}}\right)\end{array}$ & & $\begin{array}{l}\text { Human periodontal pocket, } \\
\text { Boston, USA }\end{array}$ \\
\hline C. showae & $\begin{array}{l}\text { LMG } 12635^{\mathrm{T}}(=\text { CCUG } \\
\left.30254^{\mathrm{T}}\right)\end{array}$ & & $\begin{array}{l}\text { Human, gingival crevice, } \\
\text { Showa, Japan }\end{array}$ \\
\hline C. upsaliensis & $\begin{array}{l}\text { LMG } 8850^{\mathrm{T}}(=\text { NCTC } \\
\left.11541^{\mathrm{T}}\right)\end{array}$ & & $\begin{array}{l}\text { Canine faeces, Malmo, } \\
\text { Sweden }\end{array}$ \\
\hline \multicolumn{4}{|l|}{ Related species } \\
\hline Arcobacter nitrofigilis & $\begin{array}{l}\text { LMG } 7604^{\mathrm{T}}(=\text { CCUG } \\
\left.15893^{\mathrm{T}}\right)\end{array}$ & & $\begin{array}{l}\text { Roots of Spartina } \\
\text { alterniflora, Canada }\end{array}$ \\
\hline [Bacteroides] ureolyticus & $\begin{array}{l}\text { LMG } 6451^{\mathrm{T}}(=\text { NCTC } \\
\left.10941^{\mathrm{T}}\right)\end{array}$ & & $\begin{array}{l}\text { Human, amniotic fluid, } \\
\text { Edmonton, Canada }\end{array}$ \\
\hline Campylobacter-like free-living & CCUG 13942 & & $\begin{array}{l}\text { Anaerobic sludge, } \\
\text { Netherlands }\end{array}$ \\
\hline Helicobacter pylori & $\begin{array}{l}\text { LMG } 7539^{\mathrm{T}}(=\text { NCTC } \\
\left.11637^{\mathrm{T}}\right)\end{array}$ & & $\begin{array}{l}\text { Human gastric antrum, } \\
\text { gastritis, Australia }\end{array}$ \\
\hline
\end{tabular}


Campylobacters are considered the most common bacterial cause of human enteritis worldwide $(12,37)$. Although most cases of campylobacter enteritis in man are attributed to the taxa Campylobacter jejuni subsp. jejuni, Campylobacter coli, Campylobacter lari and Campylobacter upsaliensis $(12,37)$, it has been suggested that the importance of other species also associated with gastrointestinal illness may be significantly underdiagnosed as a consequence of inappropriate isolation and identification methods $(6,20)$. Several reports support this view $(16,18)$. As part of an investigation concerning the prevalence, and potential health risk of infrequently encountered campylobacteria in common food animals, an effective procedure for isolating a broad range of species (2) was used to examine the rectal contents of healthy cattle (1). During this investigation, 44 strains, which could not be assigned to any known species of Campylobacter, Arcobacter or Helicobacter, were cultured. These strains were referred to as the catalase-negative, urease-positive campylobacter (CNUPC) group, according to their most distinctive biochemical features.

The aim of the present investigation was to classify 14 representative strains of the CNUPC group by a polyphasic taxonomic approach. Our results show that these isolates represent a previously unreported $C$. sputorum variant, for which the name $C$. sputorum bv. paraureolyticus is proposed; an additional strain from human enteritis is identified. We also present additional data demonstrating that the present criteria for delineating the named biovars of $C$. sputorum (sputorum, bubulus and fecalis) should be reviewed. We propose a revised infrasubspecific division of this species, to include the biovars sputorum, fecalis and paraureolyticus. The species description of $C$. sputorum is emended accordingly.

\section{METHODS}

Bacterial strains and growth conditions. The bacterial strains used, together with their former and present names (where appropriate) and their sources (where known), are listed in Table 1. These included 15 strains assigned to the CNUPC group [(1) and below] and 15 genetically identified (3, 33, 39; $\mathrm{P}$. Vandamme, unpublished data) type and reference strains of $C$. sputorum, representing the biovars sputorum, fecalis and bubulus. In addition, 21 type or reference strains representing the remaining species and subspecies of Campylobacter, and the related taxa Arcobacter nitrofigilis, [Bacteroides] ureolyticus, Helicobacter pylori and the unnamed free-living Campylobacter-like species of Laanbroek et al. (15), were included as study references. Strains were cultured for phenotypic characterization (24), whole-cell protein analysis (44), DNA-DNA hybridization (44) and PCR amplification of $16 \mathrm{~S}$ rDNA (24) according to previously described methods.

Phenotypic characterization. Thirty-nine phenotypic characters were recorded for each of the 51 strains listed in Table 1 . Tests were performed using the recommended media and previously described methods $(14,22-26)$. However, nalidixic acid, cephalothin, metronidazole and carbenicillincontaining media were prepared using filter-sterilized sol- utions prepared from the native antibiotic (Sigma). All tests were performed on two separate occasions, on freshly prepared media, the quality of which had been tested using appropriate control strains (S. L. W. On, unpublished data).

Numerical analysis of phenotypic tests. Procedures described previously were used (26) with one modification: results for hydrogen sulfide production in triple sugar iron agar $\left(\mathrm{H}_{2} \mathrm{~S} / \mathrm{TSI}\right)$ were not graded according to reaction intensity but recorded as positive or negative only, to account for results obtained with LMG 11761 (see below). Briefly, the simple matching coefficient was employed to calculate similarities between strains and a dendrogram was constructed to reflect these similarities. Strains were clustered by the unweighted pair group method with arithmetic averages (UPGMA). All analyses were performed using the computer program MVSP (Multi-Variate Statistical Package, version 2.01L, Kovach Computing Services, Anglesey, UK).

Extraction, separation and analysis of bacterial whole-cell proteins. Protein samples were prepared, separated by PAGE, digitized and subjected to comparative numerical analysis as described previously (31), except that points 6-107 and 141-292 of the 400 points comprising each interpolated trace were used in the analysis. The theoretical and practical reasons for this process have been discussed previously (31).

Preparation of DNA. Native DNA was prepared for DNADNA hybridization (44), and PCR amplification of $16 \mathrm{~S}$ rDNA (using a phenol/chloroform extraction procedure) (35), as described previously.

DNA-DNA hybridization experiments. The degree of DNADNA binding, expressed as a percentage, was determined spectrophotometrically by the initial renaturation rate method of De Ley et al. (8). Each value given was the mean of at least two hybridization experiments. Values of $30 \%$ DNA binding and less do not represent significant DNA homology with the method used. The total DNA concentration was $39 \mu \mathrm{g} \mathrm{ml} l^{-1}$, and the optimal renaturation temperature in $2 \times \mathrm{SSC}$ (sodium saline citrate; $1 \times \mathrm{SSC}$ is $0.15 \mathrm{M} \mathrm{NaCl}$ plus $0.015 \mathrm{M}$ sodium citrate, $\mathrm{pH} 7$ ) was $64 \cdot 6^{\circ} \mathrm{C}$.

Amplification, sequencing and analysis of 165 rDNA. PCR amplification of $16 \mathrm{~S}$ rDNA was performed using the $27 \mathrm{f} / 1392 \mathrm{r}$ primer pair (Table 2 ). The final reaction mixture $(50 \mu \mathrm{l})$ contained $1 \mu \mathrm{l}$ genomic DNA $(\sim 100 \mathrm{ng}), 0 \cdot 25 \mu \mathrm{M}$ each primer, $0.2 \mathrm{mM}$ dNTPs, $2.5 \mathrm{mM} \mathrm{MgCl}_{2}, 0.5 \mathrm{U}$ Taq DNA polymerase (Perkin-Elmer) and $1 \times$ PCR buffer (Perkin-Elmer). After an initial denaturation step $\left(94{ }^{\circ} \mathrm{C}\right.$ for $5 \mathrm{~min}$ ), the samples were subjected to 30 amplification cycles comprising denaturation $\left(94^{\circ} \mathrm{C}\right.$ for $\left.1 \mathrm{~min}\right)$, annealing $\left(55^{\circ} \mathrm{C}\right.$ for $1 \mathrm{~min}$ ) and extension $\left(72^{\circ} \mathrm{C}\right.$ for $\left.1 \mathrm{~min}\right)$, completed by a prolonged extension step $\left(72^{\circ} \mathrm{C}\right.$ for $\left.7 \mathrm{~min}\right)$. After checking the integrity of the PCR product by agarose gel electrophoresis, amplified DNA was purified for sequencing using a QIAquick PCR purification kit according to the manufacturer's recommendations (Qiagen). Sequences were determined directly using a dye terminator cycle sequencing kit under conditions recommended by the manufacturer (Applied Biosystems) using the eight primers listed in Table 2. Sequencing reactions were run on an Applied Biosystems model 373A automated DNA sequencer, using the manufacturer's recommendations. The percentage similarity between the sequence determined for CNUPC strain BU 112B (GenBank accession no. AFO22768), and all other strains contained in the GenBank database, was determined 
Table 2. PCR primers used for amplification and sequencing of 165 rDNA

Conventional nomenclature of primers is used here; the number given is the number of the $E$. coli base position to which the 3'-end of the listed primer anneals: f, forward; $r$, reverse. Single-letter codes are standard International Union of Biochemistry codes for bases and ambiguity.

\begin{tabular}{|ll|}
\hline Primer & \multicolumn{1}{c|}{ Sequence $\left(\mathbf{5}^{\prime} \rightarrow \mathbf{3}^{\prime}\right)$} \\
\hline $27 \mathrm{f}$ & AGA GTT TGA TCM TGG CTC AG \\
$518 \mathrm{r}$ & GTA TTA CCG CGG CTG CTG G \\
$536 \mathrm{f}$ & CAG CAG CCG CGG TAA TAC \\
$787 \mathrm{r}$ & GGA CTA CHA GGG TAT CTA AT \\
$806 \mathrm{f}$ & ATT AGA TAC CCT DGT AGT CC \\
$1054 \mathrm{r}$ & ACG AGC TGA CGA CRR CCA TG \\
$1073 \mathrm{f}$ & TGG TTG TCG TCA GCT CGT \\
$1392 \mathrm{r}$ & ACG GGC GGT GTG TRC \\
\hline
\end{tabular}

using the FASTA program (30) provided as part of the GCG package (10).

\section{RESULTS}

\section{Phenotypic characterization}

All of the 30 C. sputorum strains studied (including members of the CNUPC group) were Gram-negative ' $S$ '-shaped and/or curved rods when examined under microscopy. Phenotypic variation between strains was minimal; a detailed report of the species' phenotype is given below in the emended description. Reproducible differences in six tests allowed isolates to be divided into seven biochemical variants (described below). One variation noted was in the production of $\mathrm{H}_{2} \mathrm{~S}$ in TSI medium. Most (28/30) of the $C$. sputorum strains examined consistently produced copious quantities of $\mathrm{H}_{2} \mathrm{~S}$ in TSI. However, LMG 11761 yielded copious and trace amounts of $\mathrm{H}_{2} \mathrm{~S}$ in TSI medium, respectively, on the two occasions it was tested. In addition, LMG 14261 gave a negative result on both occasions. Consequently, the $\mathrm{H}_{2} \mathrm{~S} /$ TSI test was recorded only as positive or negative and was not scored according to intensity of reaction, as done previously $(21,26)$.

Several tolerance tests gave results which were not wholly reproducible and could not be used to define variation. These tests, and the corresponding percentage of strains giving a reproducible result (in parentheses), were growth on: $1.0(45 \%), 1.5(96 \%)$ and $2.0 \%(59 \%)$ bile; $3.5(86 \%)$ and $4.0 \%(83 \%)$ sodium chloride; and $0.02 \%$ safranin $(69 \%)$. Nonetheless, all $C$. sputorum bv. sputorum, $C$. sputorum bv. fecalis and CNUPC group strains could be distinguished from each other and from other Campylobacter species on the basis of their phenotypic characteristics (Table 3).

\section{Numerical analysis of phenotypic tests}

Only those phenotypic characters yielding fully reproducible results were used in the numerical analysis. Examination of the dendrogram produced (Fig. 1) showed that 18 phenons were formed at the $89 \%$ similarity (S-) level. Thirteen phenons comprised single strains included as study references, whilst strains of Campylobacter gracilis, Campylobacter hyointestinalis (both subspecies) and $C$. fetus (both subspecies) were also contained in discrete clusters. The remaining two phenons respectively included the closely related catalase-negative enteropathogenic species Campylobacter upsaliensis and Campylobacter helveticus; and 30 strains of $C$. sputorum, including 15 strains assigned to the CNUPC group. Furthermore, within the $C$. sputorum cluster, seven subphenons were formed at the $98 \% \mathrm{~S}$-level, each defined by a particular phenotype. Subphenon I contained the type strain of C. sputorum and five other catalase-negative isolates of human, bovine, ovine and porcine origin, whilst subphenon II comprised strains of ovine and bovine fecal origin that were catalase-positive (bv. fecalis). Subphenon III was a single ovine fecal strain differing from those of subphenon II only in its inability to reduce nitrate. Subphenon IV contained an ovine strain resembling subphenon I, but resistant to metronidazole $\left(4 \mathrm{mg} \mathrm{l}^{-1}\right)$ when tested on a nutrient agar base. Subphenon V contained 13 cattle isolates originally classified as the CNUPC group (and therefore catalase-negative, urease-positive), in addition to a human diarrhoeal isolate (LMG 11764). Subphenon VI comprised a single cattle CNUPC isolate differing from the other strains of this phenotype only in its tolerance to cephalothin $\left(32 \mathrm{mg} \mathrm{l}^{-1}\right)$. Subphenon VII contained a catalase-negative strain isolated from human pus, unique in that the $\mathrm{H}_{2} \mathrm{~S} /$ TSI test was negative.

\section{Numerical analysis of whole-cell protein profiles}

Forty strains were used in the analysis, including five CNUPC strains representing each of the three genotypes determined by macrorestriction profiling (1). A further $16 C$. sputorum strains were included, in addition to 19 type and reference strains of other taxa. The dendrogram produced (Fig. 2) clearly identified the CNUPC group as highly related to a human strain also giving the CNUPC phenotype (LMG 11764), and clustered these strains with 13 other C. sputorum strains at the $69 \% \mathrm{~S}$-level, clearly separating these strains from all other taxa included. The aberrant position of two C. sputorum strains (LMG 8535 and LMG 10388) in the dendrogram was attributed to the presence of a high-molecular-mass dense protein band in these strains, since their profiles were otherwise typical of the other C. sputorum strains studied (data not shown).

The main $C$. sputorum cluster could be further subdivided into subphenons at higher S-levels, but no single cut-off level could delineate these strains into groups corresponding with either their source, or the 
Table 3. Characteristics differentiating C. sputorum biovars from other campylobacteria

Phenotypic data on C. sputorum were as described in this study. The characteristics of the other taxa are from references (27), (29) and (45) and were determined with the same methods. + , All strains positive; - , all strains negative; $(+), 70-90 \%$ strains positive; (-), 7-29\% strains positive; v, 40-64\% strains positive. Abbreviations: Cat, catalase; Ure, urease; APho, alkaline phosphatase; Hipp, hippuricase; IA, indoxyl acetase; Gly, glycine; TTC, triphenyltetrazolium chloride; Nal, nalidixic acid.

\begin{tabular}{|c|c|c|c|c|c|c|c|c|c|c|c|}
\hline & \multicolumn{6}{|c|}{ Production of: } & \multirow{2}{*}{$\begin{array}{l}\text { Nitrate } \\
\text { reduction }\end{array}$} & \multicolumn{4}{|c|}{ Tolerance to: } \\
\hline & Cat & Ure & APho & Hipp & IA & $\mathrm{H}_{2} \mathrm{~S} / \mathrm{TSI}{ }^{*}$ & & $2.0 \% \mathrm{NaCl}$ & $1 \%$ Gly & TTC & Nal \\
\hline $\begin{array}{l}\text { C. sputorum bv. paraureolyticus } \\
\text { bv. nov. }\end{array}$ & - & + & - & - & - & + & + & + & + & - & + \\
\hline C. sputorum bv. sputorum & - & - & - & - & - & $(+)$ & + & + & + & - & + \\
\hline C. sputorum bv. fecalis & + & - & - & - & - & + & $(+)$ & + & + & - & + \\
\hline C. coli $\dagger^{2}$ & + & - & - & - & + & $\mathrm{v}$ & + & - & $(+)$ & + & $(-)$ \\
\hline C. concisus & - & - & $(+)$ & - & - & $(-)$ & $(-)$ & $(-)$ & $(-)$ & - & $(+)$ \\
\hline C. curvus & - & - & $\mathrm{v}$ & $(-)$ & $\mathrm{v}$ & $(-)$ & + & $\mathrm{v}$ & + & + & + \\
\hline C. fetus subsp. fetus & + & - & - & - & - & - & + & - & + & - & + \\
\hline C. fetus subsp. venerealis & $(+)$ & - & - & - & - & - & $(+)$ & - & $(-)$ & - & $(+)$ \\
\hline C. gracilis & $(-)$ & - & - & - & $(+)$ & - & $(+)$ & $(-)$ & + & - & $\mathrm{v}$ \\
\hline C. helveticus & - & - & - & - & + & - & + & $(-)$ & $\mathrm{v}$ & - & - \\
\hline $\begin{array}{l}\text { C. hyointestinalis subsp. } \\
\text { hyointestinalis }\end{array}$ & + & - & - & - & - & $(+)$ & + & - & + & $(-)$ & + \\
\hline $\begin{array}{l}\text { C. hyointestinalis subsp. } \\
\text { lawsonii }\end{array}$ & + & - & $(-)$ & - & - & $(+)$ & + & - & $(-)$ & - & + \\
\hline C. jejuni subsp. doylei & $(+)$ & - & - & + & + & - & - & - & $(-)$ & $\mathrm{v}$ & - \\
\hline C. jejuni subsp. jejuni & + & - & - & + & + & - & + & - & $(+)$ & $(+)$ & - \\
\hline C. lari & + & $\mathrm{v}$ & $(-)$ & - & $(-)$ & - & + & $(+)$ & + & $(+)$ & $(-)$ \\
\hline C. mucosalis & - & - & $(+)$ & - & - & + & $(-)$ & $(+)$ & $\mathrm{v}$ & - & $(+)$ \\
\hline C. rectus & $(-)$ & - & - & - & + & - & + & $\mathrm{v}$ & + & - & $(+)$ \\
\hline C. showae & + & - & - & - & $\mathrm{v}$ & $\mathrm{v}$ & + & + & $\mathrm{v}$ & - & - \\
\hline Campylobacter sp., free-living & - & - & - & - & + & - & + & - & - & + & - \\
\hline C. upsaliensis & - & - & - & - & + & - & + & - & + & $\mathrm{v}$ & - \\
\hline A. nitrofigilis & + & + & - & - & + & - & + & + & - & - & - \\
\hline [B.] ureolyticus & $(-)$ & + & - & - & $(-)$ & - & + & + & + & - & - \\
\hline H. pylori & + & + & + & - & $(-)$ & - & - & - & - & $\mathrm{v}$ & $(+)$ \\
\hline
\end{tabular}

* Strains of $C$. sputorum and C. hyointestinalis subsp. lawsonii normally produce copious amounts of $\mathrm{H}_{2} \mathrm{~S}$ on TSI agar slopes [but see text and (29)].

$\dagger$ Includes data on C. coli strains previously described as C. hyoilei; see (45).

full extent of the biochemical variation noted here (see above). However, at the $84 \%$ S-level, three subphenons were evident. Subphenon a contained 12 urease-negative strains, whilst subphenon b consisted of six urease-positive isolates. Subphenon c comprised LMG 14261, a strain unique in its inability to produce hydrogen sulfide.

\section{DNA-DNA hybridizations}

Six representative strains of $C$. sputorum (including the human strain assigned to the CNUPC group) and type strains of four other Campylobacter spp., were chosen for DNA homology studies. DNA binding values ranging from $82-96 \%( \pm 6 \%)$ were obtained between strains of $C$. sputorum, whilst comparable values between $C$. sputorum and each of the type strains of four distinct Campylobacter spp. were $\leqslant 22 \%$ (Table 4).

\section{PCR amplification and sequence analysis of 16S rDNA}

The size of the 16S rDNA PCR product of cattle isolate BU 112B obtained by use of primers $27 \mathrm{f}$ and $1392 \mathrm{r}$ was estimated as approximately $1650 \mathrm{bp}$, some $250 \mathrm{bp}$ larger than that expected for other Campylobacter spp., but equivalent to that expected for $C$. sputorum due to the presence of an internal transcribed spacer (40). The sequencing primers used (Table 2) enabled a sequence of 1561 bases of the rRNA gene to be determined (representing approx. $90 \%$ of the rRNA gene); the sequence of the first 200 bases was resolved in the forward direction only. Nucleotide sequence similarity searching of the GenBank database with the program FASTA (30) identified the most closely related 


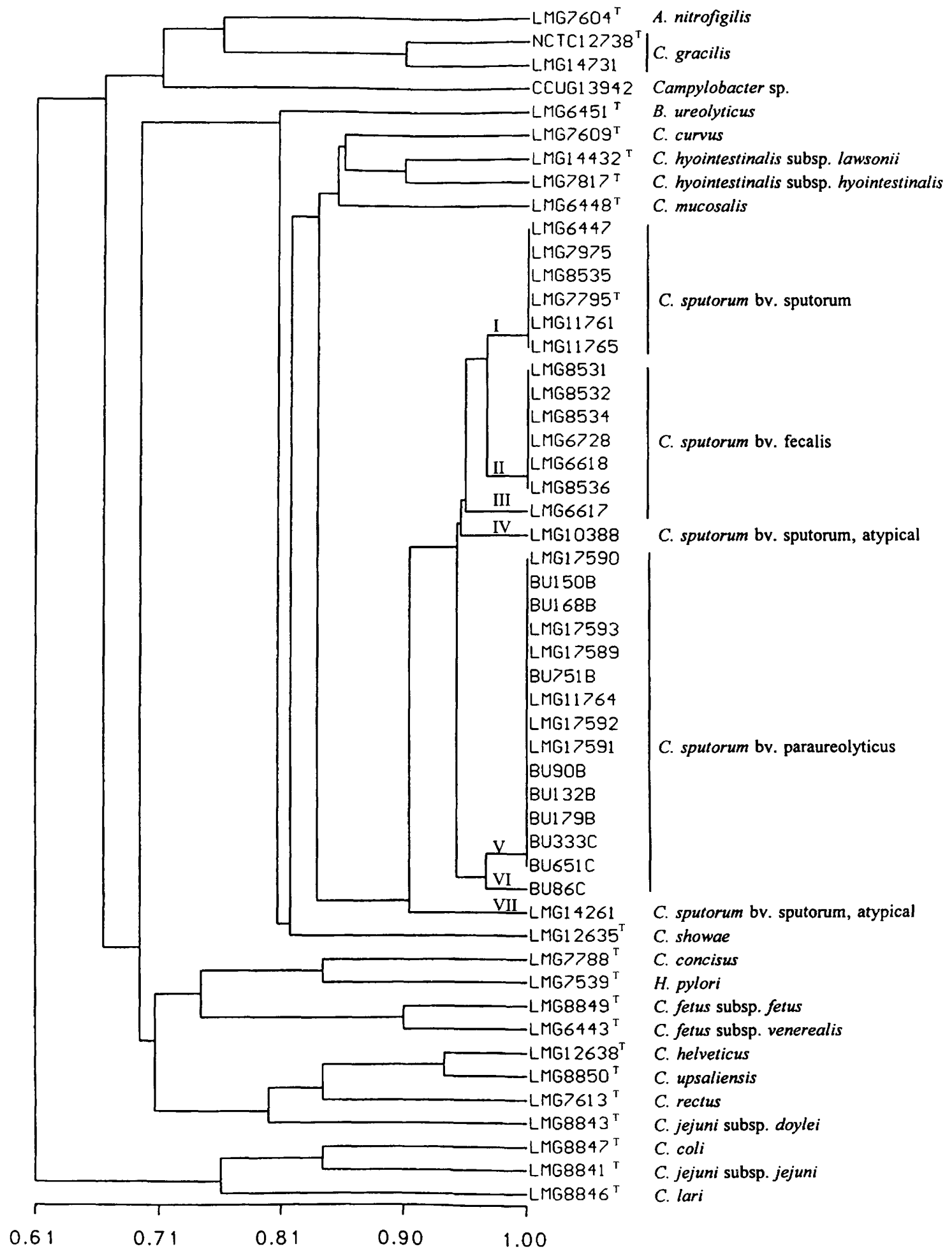

Fig. 1. Dendrogram of the cluster analysis based on phenotypic data of strains examined. The numbers on the horizontal axis indicate the percentage similarities as determined by the simple matching coefficient and UPGMA clustering. Phenons were formed at the $89 \%$ similarity (S-) level, with subphenons of $C$. sputorum (indicated by roman numerals) delineated at the $98 \%$ S-level.

sequence to BU 112B (accession no. AFO22768) as that of the 16S rRNA gene sequence of the type strain of C. sputorum (LMG $7795^{\mathrm{T}}$ : accession no. X67775)
(40), with which it showed $99.7 \%$ similarity. Of the five base differences, four were found to occur within the internal transcribed spacer region (Fig. 3). 


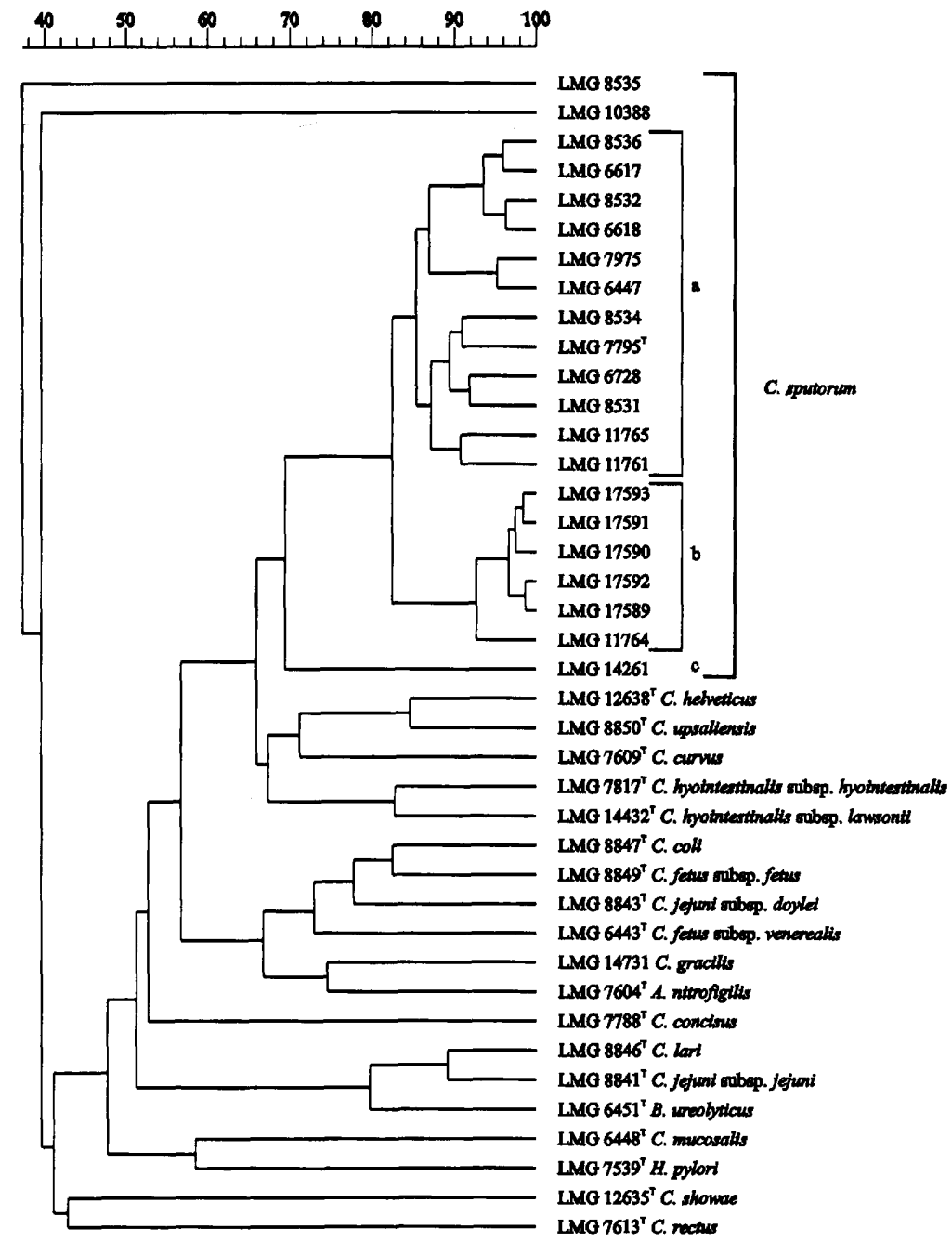

Fig. 2. Dendrogram of the cluster analysis based on partial protein profiles of strains examined. The numbers on the horizontal axis indicate the percentage similarities as determined by the Pearson productmoment correlation coefficient and UPGMA clustering. Phenons were formed at the $69 \%$ S-level, with subphenons of the principal C. sputorum cluster (indicated by lower-case letters) delineated at the $84 \% \mathrm{~S}$ level.

Table 4. DNA-DNA hybridization values of $C$. sputorum strains

\begin{tabular}{|c|c|c|c|c|c|c|c|}
\hline \multirow{2}{*}{$\begin{array}{l}\text { C. sputorum } \\
\text { biovar }\end{array}$} & \multirow[t]{2}{*}{ Strain no. } & \multicolumn{6}{|c|}{ Campylobacter reference strains: } \\
\hline & & $\begin{array}{l}\text { C. sputorum } \\
\text { bv. sputorum } \\
\text { LMG } 7795^{T}\end{array}$ & $\begin{array}{c}\text { C. sputorum } \\
\text { bv. fecalis } \\
\text { LMG } 6617\end{array}$ & $\begin{array}{c}\text { C. coli } \\
\text { LMG } 8847^{\mathrm{T}}\end{array}$ & $\begin{array}{c}\text { C. concisus } \\
\text { LMG }^{7788^{\mathrm{T}}}\end{array}$ & $\begin{array}{c}\text { C. fetus } \\
\text { subsp. fetus } \\
\text { LMG 8849' }\end{array}$ & $\begin{array}{c}C . \text { jejuni } \\
\text { subsp. jejuni } \\
\text { LMG 8841 }^{\mathrm{T}}\end{array}$ \\
\hline paraureolyticus & LMG 11764 & 89 & & & & & \\
\hline sputorum & LMG 7975 & & 83 & & & & \\
\hline sputorum & LMG 11761 & 89 & & & & & \\
\hline sputorum & LMG 11765 & 92 & & & & & \\
\hline fecalis & LMG 6617 & 82 & 100 & & 7 & 14 & 22 \\
\hline fecalis & LMG 6618 & & 96 & 21 & & & \\
\hline
\end{tabular}

\section{DISCUSSION}

Classification of the CNUPC group as C. sputorum, identification of a human isolate, and proposal of $C$. sputorum bv. paraureolyticus

Numerical analyses of both phenotypic tests and protein profiles clearly indicated the CNUPC group to be a homogeneous taxon, and also assigned a human strain, LMG 11764 (not originally included in the original study group from cattle faeces) to this group. Moreover, the CNUPC group was shown to be highly related to type and reference strains of $C$. sputorum in each analysis. The concordance of numerical analysis of protein profiles with DNA-DNA hybridization data is well-known $(21,31,44-45)$ and was again confirmed in this study, where the genomic relatedness 
$\mathrm{X} 67775$

255 - AAGCTTTATATTAATAAAGCGAAAAAAAAGC-285

*

*
Fig. 3. Alignment of a $31 \mathrm{bp}$ region of the $16 \mathrm{~S}$ rRNA gene insertion sequences of $X 67775$ (C. sputorum bv. sputorum, LMG $\left.7795^{\top}\right)$ (40) with the corresponding region of AFO22768 (C. sputorum bv. paraureolyticus, BU 112B), summarizing the differences (asterisks) (including alignment gaps indicated by full stops) between the two sequences. Bases are numbered according to sequences submitted to GenBank.

of the human CNUPC strain to selected $C$. sputorum isolates was shown to be well within the range expected for a single species (47) (Table 4). It is also noteworthy that LMG 11764 was identified as a $C$. sputorum isolate by use of a species-specific PCR assay based on a variable region of the $23 \mathrm{~S}$ rRNA gene (3), but no phenotypic data were presented by these authors. Furthermore, the $16 \mathrm{~S}$ rDNA sequence of a typical bovine CNUPC strain (LMG 17590) was 99.7\% similar to that of the type strain of $C$. sputorum and contained an insert of about $250 \mathrm{bp}$, a feature characteristic of this species (40). Although urease activity is considered an unusual feature among other taxa belonging to the Campylobacteraceae (41), these data clearly identify the CNUPC group as a novel biovar for which we propose the name $C$. sputorum bv. paraureolyticus (formal description is given below).

\section{Re-evaluation of the existing infrasubspecific (biovar) divisions of $C$. sputorum}

The original concept of the infrasubspecific division of this species was based on one fundamental principle: that certain biochemical characteristics could be used to differentiate $C$. sputorum strains isolated from particular sources and believed to be host-specific (19, 33). Strains from the human oral cavity (bv. sputorum), the bovine and ovine genital tract (bv. bubulus), and ovine faeces (bv. fecalis) are traditionally differentiated by their catalase reaction (only bv. fecalis produces catalase) and tolerance to $3.5 \% \mathrm{NaCl}$ and $1 \%$ bile (bv. sputorum giving a negative and positive result, respectively, in these two tests) (33). However, the validity of this infrasubspecific division has been questioned, since the results of tolerance tests using various concentrations of $\mathrm{NaCl}$ and ox bile are not reproducible (22-23, this study). The continued use of tolerance to $\mathrm{NaCl}$ and ox bile as determinative phenotypic markers for biovars of $C$. sputorum strains isolated from differing sources is clearly unjustified. Although tolerance to $0.02 \%$ safranin was shown to be a potential marker for certain bovine strains of $C$. sputorum (22), our data show that CNUPC strains do not give reproducible results in the latter test (see above). Indeed, no phenotypic traits unequivocally differentiate catalase- and urease-negative strains from human, bovine, porcine and ovine sources (22, this study).

Although tolerance test results are inappropriate for defining 'source-specific biovars' of $C$. sputorum, it is equally clear that a useful infrasubspecific division of the species can be achieved by the determination of catalase and urease activity. The validity of such a division is strongly supported by the correlation between the aforementioned enzyme activities and the results of numerical analyses of whole-cell protein profiles of $C$. sputorum, as determined in this study (for urease-positive strains) and a previous investigation (for catalase-positive and -negative strains) (22). Moreover, catalase and urease tests are extremely reliable when used to characterize campylobacteria (25), and this feature is clearly important in considering the definition of a biovar. The additional phenotypic diversity observed among $C$. sputorum strains examined here (in nitrate, $\mathrm{H}_{2} \mathrm{~S} / \mathrm{TSI}$, cephalothin and metronidazole tests) may eventually lead to the definition of additional biovars, but at present the limited number of strains showing these phenotypes make such proposals inappropriate. We conclude that three named biovars of $C$. sputorum should be recognized according to their ability to produce catalase and urease: bv. sputorum (negative in both tests), bv. fecalis (produces catalase only) and bv. paraureolyticus (produces urease only). We recommend that strains previously assigned to bv. bubulus be redesignated as bv. sputorum, unless phenotypic or pathological properties which reliably differentiate catalase-negative strains of bovine, porcine, ovine and human origin can be identified.

C. sputorum is largely regarded as a commensal in the hosts in which it is found $(33,37)$. However, cases of enteritis (18, 33; this study), abscess formation and other skin lesions $(4,28,33$, this study) and bronchitis (38) in humans have been reported. Moreover, both $C$. sputorum bv. paraureolyticus and bv. sputorum have been isolated from food animals and human infectious material $(4,18,28,33$; this study). The use of sensitive isolation (6) and accurate identification procedures (20) are thus required to properly determine the role of $C$. sputorum in human disease and consequently its zoonotic potential.

\section{Emended description of Campylobacter sputorum Véron and Chatelain 1973}

Cells are non-spore-forming, Gram-negative rods $(0.3-0.5 \mu \mathrm{m}$ wide and $2-4 \mu \mathrm{m}$ long) which are curved or loosely helical (' $\mathrm{S}$ '-shaped). Motile by means of a single, unsheathed, polar flagellum. Glucose is not fermented or oxidized. Optimal growth occurs under microaerobic (about $5 \% \mathrm{O}_{2}$ ) conditions, but strains will also grow anaerobically, whether or not trimethylamine- $N$-oxide (TMAO, $0 \cdot 1 \%$ ) is present in the growth medium. No growth occurs in air or at room temperature $\left(18-22^{\circ} \mathrm{C}\right)$ under microaerobic conditions. After $72 \mathrm{~h}$ growth on $5 \%$ blood agar at $37{ }^{\circ} \mathrm{C}$, colonies are circular, convex, and $1.0-2.0 \mathrm{~mm}$ in diameter. Pitting of the agar around the area of bacterial growth is not seen. A greenish colouration, 
accompanied by $\alpha$-haemolytic activity, is often observed, although this feature is inconsistent for some strains. Oxidase is produced. Most strains reduce nitrate. Hydrolysis of alkaline phosphatase, DNA, hippurate and indoxyl acetate is not observed. Triphenyltetrazolium chloride (TTC) is not reduced. Most strains produce copious quantities of $\mathrm{H}_{2} \mathrm{~S}$ in TSI medium, but occasionally a weaker or even negative result may be observed. Strains grow in the presence of $1 \%$ glycine, $2 \% \mathrm{NaCl}$, nalidixic acid $\left(32 \mathrm{mg} \mathrm{l}^{-1}\right)$, and $0.032 \%$ methyl orange: a few strains demonstrate tolerance to metronidazole $\left(4 \mathrm{mg} \mathrm{l}^{-1}\right.$, using a nutrient agar base) or cephalothin ( $32 \mathrm{mg} \mathrm{l}^{-1}$, blood agar base). Strains do not grow in the presence of $0.04 \%$ TTC, $0.1 \% \mathrm{KMnO}_{4}$, or pyronin $(0.02 \%$, nutrient and blood agar base media). The $\mathrm{G}+\mathrm{C}$ content of the DNA from C. sputorum is $30-33 \mathrm{~mol} \%(33,43)$. The pathogenic potential of $C$. sputorum is unknown.

Strains of $C$. sputorum may be assigned to one of three biovars according to their reaction in two tests, catalase and urease. Campylobacter sputorum bv. sputorum comprises catalase- and urease negative strains that have been found in the oral cavity, faeces (normal and diarrhoetic) and abscesses (and other skin lesions) of humans; the genital tract of bulls; abortions in sheep; and the faeces of sheep and pigs. Campylobacter sputorum bv. fecalis comprises catalase-positive, urease-negative strains that have been isolated from ovine and bovine faeces. LMG 8531 is recommended as a reference strain.

\section{Description of Campylobacter sputorum bv. paraureolyticus bv. nov.}

Campylobacter sputorum bv. paraureolyticus bv. nov. (para.ureo.lyt'ic.us. Gr. prep. para alongside of, resembling; M.L. ureolyticus specific epithet, paraureolyticus resembling Bacteroides ureolyticus, a ureaseproducing bacterium closely related to other Campylobacter spp.).

Comprises catalase-negative, urease-positive strains isolated from human diarrhoea and bovine faeces. LMG 11764 (human) and LMG 17590 (= CCUG 37579) (bovine) are recommended reference strains. The type strain of $C$. sputorum belongs to bv. sputorum and is LMG 7795 $5^{\mathrm{T}}$ (= CCUG $9728=$ NCTC $11528=$ ATCC 35980) and shows phenotypic properties typical of the species (see above). This strain was isolated from the human oral cavity. The $\mathrm{G}+\mathrm{C}$ content of its DNA is 31 (43) to $32 \mathrm{~mol} \%$ (33).

\section{ACKNOWLEDGEMENTS}

We are indebted to Enevold Falsen (Culture Collection of the University of Göteborg, Sweden) for his invaluable support by the kind provision of reference strains. P.V. is grateful to the Fund for Scientific Research-Flanders (Belgium) for a position as a senior research assistant. C.S.H. is indebted to the European Molecular Biology
Organization (EMBO, Germany) for a short-term Fellowship award. H.I.A. and J.E.L.C. are grateful to Kafkas University (Turkey) for financial support. H.I.A. is also grateful to the Federation of European Microbiological Societies (FEMS) for a Fellowship award. C.S.H. and S.L.W.O. thank P. Ahrens and K. Vestergaard for their expert assistence with the AutoAssembler software for the ABI sequencer. This work benefited from the use of the SEQNET facility (Daresbury, UK).

\section{REFERENCES}

1. Atabay, H. I., Corry, J. E. L. \& On, S. L. W. (1997). Isolation and characterization of a novel catalase-negative, ureasepositive Campylobacter from cattle faeces. Lett Appl Microbiol 24, 59-64.

2. Atabay, H. I., Corry, J. E. L. \& Post, D. E. (1996). Comparison of the productivity of a variety of selective media for Campylobacter and Arcobacter species. In Campylobacter VIII. Proceedings of the 8th International Workshop on Campylobacter, Helicobacter, and Related Organisms, pp. 19-23. Edited by D. G. Newell, J. Ketley \& R. A. Feldman. New York: Plenum.

3. Bastyns, K., Chapelle, S., Vandamme, P., Goossens, H. \& De Wachter, R. (1994). Species-specific detection of campylobacters important in veterinary medicine by PCR amplification of 23S rDNA areas. Syst Appl Microbiol 17, 563-568.

4. Borczyk, A., Lior, H., McKeown, A. \& Svendsen, H. (1988). Isolations of Campylobacter sputorum associated with human infections. In Campylobacter IV. Proceedings of the Fourth International Workshop on Campylobacter Infections, Göteborg, Sweden, pp. 166-167. Edited by B. Kaijser \& E. Falsen. Sweden: University of Göteborg.

5. Charlier, G., Dekeyser, P., Florent, A., Strobbe, R. \& De Ley, J. (1974). DNA base composition and biochemical characters of Campylobacter strains. Antonie Leeuwenhoek $\mathbf{4 0}$, 145-151.

6. Corry, J. E. L., Post, D. E., Colin, P. \& Laisney, M. J. (1995). Culture media for the isolation of campylobacters. Int $J$ Food Microbiol 26, 43-76.

7. Costas, M., Owen, R. J. \& Jackman, P. J. H. (1987). Classification of Campylobacter sputorum and allied campylobacters based on numerical analysis of electrophoretic protein patterns. Syst Appl Microbiol 9, 125-131.

8. De Ley, J., Cattoir, H. \& Reynaerts, A. (1970). The quantitative measurement of DNA hybridization from renaturation rates. Eur J Biochem 12, 133-142.

9. Firehammer, B. D. (1965). The isolation of vibrios from ovine feces. Cornell Vet 55, 482-494.

10. Genetics Computer Group (1994). Program manual for the Wisconsin package, version 8, August 1994. Genetics Computer Group, Madison, Wisconsin, USA.

11. Goodwin, C. S., Armstrong, J. A., Chilvers, T., Peters, M., Collins, M. D., Sly, L., McConnell, W. \& Harper, W. E. S. (1989). Transfer of Campylobacter pylori and Campylobacter mustelae to Helicobacter gen. nov. as Helicobacter pylori comb. nov. and Helicobacter mustelae comb. nov. respectively. Int J Syst Bacteriol 39, 397-405.

12. Griffiths, P. L. \& Park, R. W. A. (1990). Campylobacters associated with human diarrhoeal disease. $J$ Appl Bacteriol 69, 281-301.

13. Harvey, S. M. \& Greenwood, J. R. (1983). Relationships 
among catalase-positive campylobacters determined by deoxyribonucleic acid-deoxyribonucleic acid hybridization. Int $J$ Syst Bacteriol 33, 275-284.

14. Holmes, B., On, S. L. W., Ganner, M. \& Costas, M. (1992). Some new applications of probabilistic identification. In Proceedings of the 1992 Conference on Taxonomy and Automated Identification of Bacteria, Prague, Czechoslovakia, pp. 6-9. Edited by J. Schindler. Prague: Czechoslovak Society for Microbiology.

15. Laanbroek, H. J., Kingma, W. \& Veldkamp, H. (1977). Isolation of an aspartate-fermenting, free-living Campylobacter species. FEMS Microbiol Lett 1, 99-102.

16. Lastovica, A., Le Roux, E., Warren, R. \& Klump, H. (1993). Clinical isolates of Campylobacter mucosalis. J Clin Microbiol 31, 2835-2836.

17. Lawson, G. H. K., Leaver, J. L., Pettigrew, G. W. \& Rowland, A. C. (1981). Some features of Campylobacter sputorum subsp. mucosalis subsp. nov., nom. rev. and their taxonomic significance. Int J Syst Bacteriol 31, 385-391.

18. Lindblom, G.-B., Sjögren, E., Hansson-Westerberg, J. \& Kaijser, B. (1995). Campylobacter upsaliensis, C. sputorum sputorum and C. concisus as common causes of diarrhoea in Swedish children. Scand J Infect Dis 27, 187-188.

19. Loesche, W. J., Gibbons, R. J. \& Socransky, S. S. (1965). Biochemical characteristics of Vibrio sputorum and relationship to Vibrio bubulus and Vibrio fetus. J Bacteriol 89, 1109-1116.

20. On, S. L. W. (1996). Identification methods for campylobacters, helicobacters, and related organisms. Clin Microbiol Rev 9, 405-422.

21. On, S. L. W., Bloch, B., Holmes, B., Hoste, B. \& Vandamme, P. (1995). Campylobacter hyointestinalis subsp. lawsonii subsp. nov., isolated from the porcine stomach, and an emended description of Campylobacter hyointestinalis. Int $J$ Syst Bacteriol 45, 767-774.

22. On, S. L. W., Costas, M. \& Holmes, B. (1994). Classification and identification of Campylobacter sputorum using numerical analyses of phenotypic tests and of whole-cell protein profiles. Syst Appl Microbiol 17, 543-553.

23. On, S. L. W. \& Holmes, B. (1991). Effect of inoculum size on the phenotypic characterisation of Campylobacter species. $J$ Clin Microbiol 29, 923-926.

24. On, S. L. W. \& Holmes, B. (1991). Reproducibility of tolerance tests that are useful in the identification of campylobacteria. $J$ Clin Microbiol 29, 1785-1788.

25. On, S. L. W. \& Holmes, B. (1992). Assessment of enzyme detection tests useful in identification of campylobacteria. $J$ Clin Microbiol 30, 746-749.

26. On, S. L. W. \& Holmes, B. (1995). Classification and identification of campylobacters, helicobacters and allied taxa by numerical analysis of phenotypic tests. Syst Appl Microbiol 18, 374-390.

27. On, S. L. W., Holmes, B. \& Sackin, M. (1996). A probability matrix for the identification of campylobacters, helicobacters, and allied taxa. $J$ Appl Bacteriol 81, 425-432.

28. On, S. L. W., Ridgwell, F., Cryan, B. \& Azadian, B. S. (1992). Isolation of Campylobacter sputorum biovar sputorum from an axillary abscess. $J$ Infect $\mathbf{2 4}, 175-179$.

29. On, S. L. W. \& Vandamme, P. (1997). Identification and epidemiological typing of Campylobacter hyointestinalis subspecies by phenotypic and genotypic methods and description of novel subgroups. Syst Appl Microbiol 20, 238-247.

30. Pearson, W. R. (1990). Rapid and sensitive sequence comparison with FASTP and FASTA. Methods Enzymol 183, 63-98.

31. Pot, B., Vandamme, P. \& Kersters, K. (1994). Analysis of electrophoretic whole-organism protein fingerprints. In Modern Microbial Methods (Chemical Methods in Prokaryotic Systematics series), pp. 493-521. Edited by M. Goodfellow \& A. G. O'Donnell. Chichester: Wiley.

32. Prévot, A. R. (1940). Études de systématique bactérienne. V. Essai de classification des vibrions anaérobies. Ann Inst Pasteur 64, 117-125.

33. Roop, R. M., II, Smibert, R. M., Johnson, J. L. \& Krieg, N. R. (1985). DNA homology studies of the catalase-negative campylobacters and 'Campylobacter fecalis', an emended description of Campylobacter sputorum, and proposal of the neotype strain of Campylobacter sputorum. Can J Microbiol 31, 823-831.

34. Roop, R. M., II, Smibert, R. M., Johnson, J. L. \& Krieg, N. R. (1985). Campylobacter mucosalis (Lawson, Leaver, Pettigrew and Rowland 1981) comb. nov.: emended description. Int J Syst Bacteriol 35, 189-192.

35. Sambrook, J., Fritsch, E. F. \& Maniatis, T. (1989). Molecular Cloning: a Laboratory Manual, 2nd edn. Cold Spring Harbor, NY: Cold Spring Harbor Laboratory.

36. Sebald, M. \& Véron, M. (1963). Teneur en bases de l'ADN et classification des vibrions. Ann Inst Pasteur 105, 897-910.

37. Skirrow, M. B. (1994). Diseases due to Campylobacter, Helicobacter and related bacteria. J Comp Pathol 111, 113-149.

38. Tunnicliff, R. (1914). An anaerobic vibrio isolated from a case of acute bronchitis. $J$ Infect Dis 15, 350-351.

39. Ursing, J. \& Firehammer, B. D. (1985). Genetic relationship between 'Campylobacter fecalis' and Campylobacter sputorum subsp. bubulus. Acta Pathol Microbiol Immunol Scand Sect B 93, 377-378.

40. Van Camp, G., De Peer, Y. V., Nicolai, S., Neefs, J.-M., Vandamme, P. \& De Wachter, R. (1993). Structure of $16 \mathrm{~S}$ and 23S ribosomal RNA genes in Campylobacter species: phylogenetic analysis of the genus Campylobacter and presence of internal transcribed spacers. Syst Appl Microbiol 16, 361-368.

41. Vandamme, P., Danashvar, M. I., Dewhirst, F. E., Paster, B. J., Kersters, K., Goossens, H. \& Moss, C. W. (1995). Chemotaxonomic analyses of Bacteroides gracilis and Bacteroides ureolyticus and reclassification of $B$. gracilis as Campylobacter gracilis comb. nov. Int J Syst Bacteriol 45, 145-152.

42. Vandamme, P. \& De Ley, J. (1991). Proposal for a new family, Campylobacteraceae. Int J Syst Bacteriol 41, 451-455.

43. Vandamme, P., Falsen, E., Rossau, R., Hoste, B., Segers, P., Tytgat, R. \& De Ley, J. (1991). Revision of Campylobacter, Helicobacter, and Wolinella taxonomy: emendation of generic descriptions and proposal of Arcobacter gen. nov. Int $J$ Syst Bacteriol 41, 88-103.

44. Vandamme, P., Vancanneyt, M., Pot, B., Mels, L., Hoste, B., Dewettinck, D., Vlaes, L., Van Den Borre, C., Higgins, R., Kersters, K., Butzler, J.-P. \& Goossens, H. (1992). Polyphasic taxonomic study of the emended genus Arcobacter with Arcobacter butzleri comb. nov. and Arcobacter skirrowii sp. nov., an aerotolerant bacterium isolated from veterinary specimens. Int J Syst Bacteriol 42, 344-356.

45. Vandamme, P., Van Doorn, L.-J., Al Rashid, S. T., Quint, W. G. 
V., Chan, V. L., Van der Plads, J. \& On, S. L. W. (1997). Campylobacter hyoilei Alderton et al. 1995 and Campylobacter coli Véron and Chatelain 1973 are subjective synonyms. Int J Syst Bacteriol 47, 1055-1060.

46. Véron, M. \& Chatelain, R. (1973). Taxonomic study of the genus Campylobacter Sebald and Véron and designation of the neotype strain for the type species, Campylobacter fetus
(Smith and Taylor) Sebald and Véron. Int $J$ Syst Bacteriol 23, 122-134.

47. Wayne, L. G., Brenner, D. J., Colwell, R. R. \& 9 other authors (1987). International Committee on Systematic Bacteriology. Report of the ad hoc committee on reconciliation of approaches to bacterial systematics. Int J Syst Bacteriol 37, 463-464. 